I NTERNATIONALMONETARY FUND

Monetary and Capital Markets Department

\title{
Risk Management and Regulation
}

\section{Tobias Adrian}

No. $18 / 13$ 
Monetary and Capital Markets Department

\section{Risk Management and Regulation}

Tobias Adrian

$\begin{array}{llllllllllllllllllllllll}\text { I N T } & \text { E R } & \text { N A T I O N } & \text { A L } & \text { M O } & \text { N E } & \text { T A } & \text { R } & \text { Y } & \text { F } & \text { U N } & \text { D }\end{array}$ 
Copyright (O2018

International Monetary Fund

\section{Cataloging-in-Publication Data}

Joint Bank-Fund Library

Names: Adrian, Tobias, 1971- | International Monetary Fund. | International Monetary Fund. Research Department.

Title: Risk management and regulation / Tobias Adrian.

Other titles: Departmental paper series (International Monetary Fund. Research Department)

Description: Washington, DC : International Monetary Fund, 2018. | At head of title: Research Department. |

Prepared for the 20th anniversary volume of the Journal of risk. | Includes bibliographical references.

Identifiers: ISBN 978-1-48434-391-3 (paper)

Subjects: LCSH: Financial risk management. | Capital movements. | Stock exchanges_Law and legislation. Classification: LCC HG4026.A334 2018

The Departmental Paper Series presents research by IMF staff on issues of broad regional or cross-country interest. The views expressed in this paper are those of the author(s) and do not necessarily represent the views of the IMF, its Executive Board, or IMF management.

Publication orders may be placed online, by fax, or through the mail:

International Monetary Fund, Publication Services

P.O. Box 92780, Washington, DC 20090, U.S.A.

Tel. (202) 623-7430 Fax: (202) 623-7201

E-mail: publications@imf.org

www.imfbookstore.org

www.elibrary.imf.org 


\section{Contents}

Acknowledgments............................................................................................................v

Abstract................................................................................................................... vii

1. Foundations of Risk Management ............................................................................. 1

2. The Basel I Capital Accord..................................................................................5

3. The Rise of Bond Trading and the Quants .................................................................... 7

4. The Hardwiring of Risk Management in Capital Rules ........................................ 13

5. The Crisis of 2008......................................................................................... 19

6. Postcrisis Regulatory Innovations.............................................................. 27

7. Current Challenges ...................................................................................................... 35

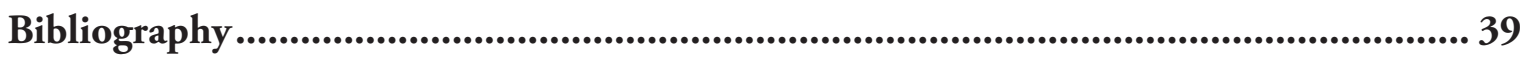

\section{Figures}

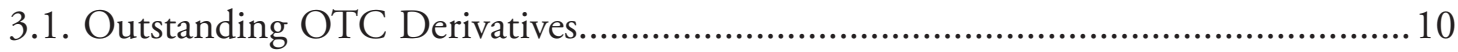

3.2a. US Private-Label Term Securitization Issuance by Type ...................................... 10

3.2b. European Private-Label Term Securitization Issuance by Type ............................. 10

3.3. Ratings of AAA-Rated US RMBS-Related Securities.......................................... 11

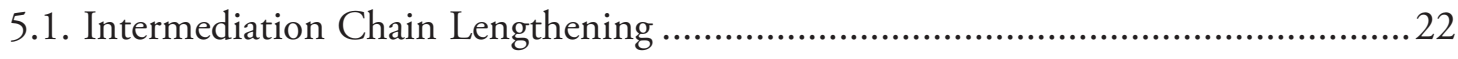

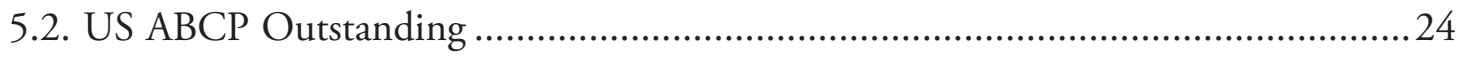

Table

5.1. Typical Haircuts on Term Securities Financing Transactions................................26 



\section{Acknowledgments}

This article was prepared for the 20th anniversary volume of the Journal of Risk. The author would like to thank Ken Garbade and Til Schuermann for comments and Pierpaolo Grippa, Nigel Jenkinson, John Kiff, and Aditya Narain for helping draft the article. The views expressed in this article are those of the author and do not necessarily represent the views of the International Monetary Fund, its Executive Directors, or its management. 



\section{Abstract}

The evolution of risk management has resulted from the interplay of financial crises, risk management practices, and regulatory actions. In the 1970s, research laid the intellectual foundations for the risk management practices that were systematically implemented in the 1980s as bond trading revolutionized Wall Street. Quants developed dynamic hedging, value-at-risk, and credit risk models based on the insights of financial economics. In parallel, the Basel I framework created a level playing field among banks across countries. Following the 1987 stock market crash, the near failure of Salomon Brothers, and the failure of Drexel Burnham Lambert, in 1996 the Basel Committee on Banking Supervision published the Market Risk Amendment to the Basel I Capital Accord; the amendment went into effect in 1998. It led to a migration of bank risk management practices toward market risk regulations. The framework was further developed in the Basel II Accord, which, however, from the very beginning was labeled as being procyclical due to the reliance of capital requirements on contemporaneous volatility estimates. Indeed, the failure to measure and manage risk adequately can be viewed as a key contributor to the 2008 global financial crisis. Subsequent innovations in risk management practices have been dominated by regulatory innovations, including capital and liquidity stress testing, macroprudential surcharges, resolution regimes, and countercyclical capital requirements. 



\section{Chapter}

\section{Foundations of Risk Management}

"Practical men who believe themselves to be quite exempt from any intellectual influence, are usually the slaves of some defunct economist." (John Maynard Keynes)

For financial firms, good risk management can mean the difference between surviving profitably and perishing in disruptive bankruptcies. For today's interconnected financial systems, it can also mean the difference between an orderly exit of weak players and a disorderly systemic event that can impact the macroeconomy. Over the years, the financial industry has made enormous investments in developing and implementing techniques that facilitate sound risk recognition, measurement, mitigation, and management. Financial regulation reinforces the incentives to promote good risk management to aid it in its objective to reduce the likelihood of individual failures and systemic distress. It does this both through high-level guidance and by requiring the use of prescribed risk measurement methodologies.

The foundations of modern risk management started with the intellectual revolution of financial economists in the 1970s, primarily at Massachusetts Institute of Technology and the University of Chicago: after years of attempts by several other economists, Fisher Black, Myron Scholes, and Robert C. Merton put option pricing on a solid basis and laid the foundations for a stream of promising developments in finance over the next 20 years-from hedging strategies and credit default models to the extraction of implied probability distributions from market prices (Black and Scholes 1973; Merton 1973).

This breakthrough came at the right time and right place to match a surging demand for risk management stemming from dramatic developments in the international economy: the collapse of the Bretton Woods system in 1971 (with the unilateral cancellation of the US dollar's convertibility into gold) 
had put an end to an era of prolonged stability in exchange and interest rates that lasted from the end of World War II through the mid-1960s, while the first oil crisis, in 1973, sparked heightened volatility in commodity and equity markets. The perverse combination of persistently high unemployment and high inflation that resulted (so-called stagflation) eventually led to the stark monetary tightening of the late '70s and early ' 80 s - starting in the United Kingdom and United States - which sent interest rates into two-digit territory in most countries.

This brought to its end an era of stable and relatively competition-free banking and put the active management of risks at center stage. Robert Merton recently put it in the following way: "There was an explosion of new risks flowing throughout the system from everywhere. The response to thatperhaps the only functional aspect of a very dysfunctional disaster-was an explosion of financial innovation. There was so much need to manage these risks." 1

Importantly, futures and derivatives trading took off in the 1970s. The Chicago Board Options Exchange opened for business in April 1973: the number of call option contracts traded on the exchange jumped from 911 on the first day of trading to 20,000 by mid-1974 and 100,000 in 1975 (Bernstein 2012). The explosion of trading derivatives laid the foundation for the over-the-counter (OTC) derivative markets and mortgage-backed securities markets that would appear soon after.

The path-breaking work of Black, Merton, and Scholes, which had provided a solution to the pricing of European "plain-vanilla" options, rapidly sparked a flurry of further developments among academics aimed at pricing options on a range of underlying instruments (for example, currencies, commodities, futures) and with more and more complex payoff features (American, Bermudan, Asian, barrier, and so on).

The pricing of interest rate derivatives (forward swaps, swaptions, bond futures and options, and so on), on the other hand, posed specific challenges, requiring the whole term structure of interest rates to be modeled. This was generally addressed via models focusing on the evolution of the short-term rate as a function of one or more factors (Cox, Ingersoll, and Ross 1985; Hull and White 1994a, 1994b; Black, Derman, and Toy 1990), while later developments focused on instantaneous forward rates (Heath, Jarrow, and Morton 1992) or market-observable forward rates (for example, the London Interbank Offered Rate market model of Brace, Gatarek, and Musiela 1997).

\footnotetext{
${ }^{1}$ Interview at Massachusetts Institute of Technology Sloan, 2013, http://mitsloan.mit.edu/newsroom/articles /black-scholes-merton-a-40-year-revolution-in-finance/.
} 
Financial innovation spread beyond derivatives and gave new impetus to more traditional segments of the financial markets-such as fixed income in the United States, where investment banks started trading the mortgage-backed securities issued by government-sponsored enterprises and using them as collateral for their transactions, and consequently structuring their own deals. This was the beginning of the golden age of Wall Street.

The advances in the theory and practice of finance were also met by significant progress in information and communication technologies that made possible the fast computation of derivatives prices (even on hand-held calculators) and swift, real-time trading possible.

A fundamental insight of the Merton (1974) framework was the interpretation of a company's debt as an option on the underlying assets; in particular, as a put option on the assets sold to shareholders. This important result was thoroughly put into practice only years later-thanks also to the pioneering work of Oldřich Vašíček (1987) on the value of a loan portfolio- - and produced a revolution in the approach to credit risk. The pricing of credit risk allowed the expansion of financial innovation from banks' trading books to their banking books. The so-called Vašíček Model showed how default probabilities can be inferred from market prices, setting the foundation for the modeling of dependency in credit portfolio models and stress-testing frameworks. The model was eventually adopted by regulators as the benchmark on which to base the risk-weighting formulas under the internal rating-based approach of the Basel II framework. But before Basel II came the Basel I Capital Accord, which laid the foundation for the design of the regulatory capital framework for the coming decades. 



\section{Chapter}

\section{The Basel I Capital Accord}

"The only reason that I keep any capital is that some fuddy-duddy directors think that it looks better." (New York banker to Paul Volcker)

The Basel Committee was initially set up as a committee of Group of Ten (G10) countries to facilitate supervisory cooperation and exchange of information following the potentially significant disruption and international spillovers that arose from the failure of a relatively small bank, Bankhaus Herstatt, in West Germany in 1974. ${ }^{1}$ Its objectives were to close gaps in the supervision of international banks and provide a consistent supervisory framework for this purpose. Its early work focused on developing proposals for home-host responsibilities in the supervision of foreign establishments, consolidated supervision, and exchange of supervisory information.

Following the Latin American debt crisis in the 1980s, the committee's concerns shifted to ensuring that the capital ratios of the major banks were adequate in the face of growing risks in their international operations, often spurred by competitive inequalities. There was no internationally agreed-upon capital adequacy framework; some supervisors relied on some version of a leverage ratio though, although both the ratio and the constituent elements of the numerator and denominator varied across jurisdictions. The result was the landmark Basel Capital Accord of 1988, which required internationally active banks in the Basel Committee member countries to maintain capital that was at least 8 percent of risk-weighted assets.

Under Basel I, credit exposures were risk weighted using a supervisory scale based on the nature of the exposure/counterparty. ${ }^{2}$ For example, exposures to sovereigns that were members of the Organisation for Economic Co-opera-

\footnotetext{
${ }^{1}$ A thorough review of the early history of the Basel Committee can be found in Goodhart (2011).

${ }^{2}$ Note that Basel I covered only credit risk. "Market risk," introduced later, does not appear at all. Of course, banks are dominated by credit risk to this day, even the ones that are primarily running trading businesses.
} 
tion and Development carried a risk weight of 0 percent; all corporate exposures carried a risk weight of 100 percent. The capital requirements could be met by a tiered capital structure that included a variety of eligible instruments ranging from shareholder's equity to hybrid debt-equity instruments and subordinated debt. Off-balance-sheet positions were converted into credit equivalents before applying risk weights. The elegance of the approach lay in its simplicity, and this led to Basel I being adopted not just by the G10 members of the Basel Committee for their internationally active banks, but by most countries around the world for their banking systems.

The minimum ratio of capital to risk-weighted assets of 8 percent quickly became the first truly global standard in bank regulation. This helped in some measure to achieve the objectives of leveling the playing field and raising capital ratios, with the major G10 banks reporting an increase in the average ratio of capital to risk-weighted assets from 9.3 percent in 1988 to 11.2 percent in 1996. Having transparent and consistent capital standards also led weakly capitalized banks to more rapidly rebuild their capital (Basel Committee on Banking Supervision [BCBS] 1999). Equally important, it represented a successful move to an international convergence of inserting some element of risk sensitivity into global regulation.

But almost as soon as Basel I was implemented around the world, the discussion turned to the need for greater risk sensitivity of the Basel I credit risk weights, which, for example, treated all corporate exposures alike irrespective of the credit quality of the counterparty. While there was agreement that the Basel I framework lacked granularity to make meaningful risk differentiation, there was less agreement on the way forward that could address the diversity in the size and scope of banks applying Basel I.

The outcome was the much more comprehensive Basel II framework, which expanded the coverage of risks and provided for a menu of approaches including the use of internal models. The framework was predicated on a three-pillar approach that brought together minimum standard regulation, supervisory discretion, and market discipline. This was a brave new world, one that sought to move away from "one size fits all" and provided an impetus for the use of quantitative techniques in risk management that used firm-specific loss experiences. But the story of the quants in modern-day risk measurement and management goes back much earlier. 


\title{
Chapter
}

\section{The Rise of Bond Trading and the Quants}

\author{
"I never thought of myself as a king." (John Gutfreund, CEO of \\ Salomon Brothers)
}

While derivative pricing was uncovered by Black and Scholes (1973) and Merton (1973), an influential contribution by Homer and Leibowitz (1972) presented much of the bond calculus that laid the foundation for the rise in fixed income trading of the 1970s and 1980s. ${ }^{1}$ Modern risk management is closely tied to the application of fixed income and derivatives calculus, as it applied the assessment of risk and return to bond portfolios. The usage of bond calculus was accelerated by deregulation, technology, and the ever-increasing market depth for fixed income securities markets.

Extreme financial market volatility drove the need for new risk management products and techniques in the 1970s and 1980s. Quantitative techniques including option pricing, bond calculus, and risk computations advanced in earlier academic work became practical with the advent of computing power.

\section{Risk Management}

Several investment banks introduced value-at-risk (VaR)-based risk management systems in the 1980s - the Bankers Trust risk-adjusted return on capital, Chase Manhattan risk-adjusted capital, and Citibank potential loss amount internal capital allocation systems. The US Securities and Exchange Commission introduced VaR-based haircuts to its Uniform Net Capital Rule. JP Morgan launched its VaR-based Riskmetrics in 1994 and CreditMetrics in 1997, two risk assessment systems that would have profound impacts on risk man-

\footnotetext{
${ }^{1}$ Macaulay's bond duration goes back to a 1938 National Bureau of Economic Research paper (Macaulay 1938), but it was only rediscovered by Fisher and Weil (1971). Fong and Vašíček (1984) suggested important improvements.
} 
agement practices across sell-side and buy-side firms (MorganGuaranty 1994; Gupton and others 1997).

Much of this rapid development owes itself to the $\mathrm{PhD}$ "quants" who crossed over to Wall Street. Notable among them were Fischer Black and Emanuel Derman at Goldman Sachs, Christopher Finger at JP Morgan, Kenneth Garbade at Bankers Trust, and Oldřich Vašíček at Wells Fargo. In an influential 1986 Bankers Trust internal paper, Garbade (1986) describes VaR measures for Treasury securities portfolios using linear and principal component mappings. ${ }^{2}$

Risk management based on VaR found its way into banking regulations, with VaR-based metrics feeding into the Basel Accord market-risk-related capital requirement calculations. In addition, the Basel II credit-risk-related capital requirements were based on Oldřich Vašíček’s 1987 "distribution of loan portfolio value" paper, which is mathematically a calculation closely related to VaR (Vašíček 1987).

The key assumption of early VaR models was that securities could be continuously traded. Hence short horizon volatility was viewed to be the relevant metric for risk management, as it is assumed that portfolios can be dynamically adjusted to stay within a certain risk level. For example, a firm that has a VaR limit for a long-term bond portfolio would have to reduce holdings when market volatility rises to stay within the $\mathrm{VaR}$ limit, and increase exposures when volatility falls to maximize return on equity. The relevant risk metric for these calculations is daily or sometimes even instantaneous volatility. And indeed, in the 1990s and 2000s the predominant approach to risk management was to use the daily, weekly, or 10-day VaR for risk management and regulatory purposes.

Of course, such an approach does not work well when assets are illiquid, as it might not be possible to adjust portfolios seamlessly by buying and selling them in the marketplace. VaR calculations based on short horizon calculations can severely underestimate risk, especially in illiquid markets. Risk managers attempted to rectify these shortcomings by complementing VaR metrics with stressed VaRs based on historical periods of market stress. But the accuracy of stressed VaRs depends on the severity of the stress assumption, and more often than not, those assumptions turned out to be unusually mild in retrospect. The 2008 crisis was more severe than any stress assumptions based on prior experience, where historical events were typically based on the time period since the 1990s.

\footnotetext{
${ }^{2}$ Risk management considerations can be traced back to Roy's (1952) "safety first" paper. The insurance industry used a "probable maximum loss" metric before that (McGuinness, 1969). The concepts underlying risk management were also mentioned in Hardy (1923) and Hicks (1935).
} 


\section{Product Proliferation}

New risk management products proliferated on the back of the new technology, spurred on by capital and risk intermediation globalization. Borrowers could issue fixed- or floating-rate bonds in one country and use currency and interest rate swaps to transform the currency or interest rate basis to a preferred structure. Swaps started out as bespoke OTC products in the early 1980s, but in the late 1980s markets became standardized based on standards set by the International Swap Dealers Association. ${ }^{3}$

Modern securitization markets have followed a similar trajectory. ${ }^{4}$ They started in the United States with Ginnie Mae's pass-through residential mortgage-backed securities (RMBS) in the 1970s. This was followed by private-label RMBS in 1977, Fannie Mae's introduction of collateralized mortgage obligations in 1983, and non-mortgage-backed, asset-backed securities (ABS) in the mid-'80s. Again a combination of regulations and technology played key roles in market evolution and growth.

Securitization was boosted by the 1988 Basel Accord and its lack of differentiation between high- and low-quality loans. It incentivized the securitization of low-risk loan portfolios and the retention of high-risk loans. Regulatory arbitrage also motivated the introduction of collateralized debt obligations (CDOs) and structured investment vehicles in the late 1980s. Starting in the late 1990s, credit default swaps were used to trade credit exposures by creating "synthetic" replication of credit risk. Figure 3.1 shows outstanding volumes in OTC derivatives markets; Figures 3.2a and 3.2b illustrate the explosion in private-label term securitization prior to the crisis.

The explosive growth of CDOs and other structured credit products from 2000 to 2006 was enabled to a great degree by an influential paper by JP Morgan strategist David X. Li (2000) on the application of copula functions to default correlation modeling. Embraced by risk managers and credit rating agencies, it facilitated the creation and sale of massive amounts of top-rated CDO tranches, from pools of lower-quality loans and other structured credit products (for example, CDO-squared). However, Li's methodology did not account for the fact that correlations among portfolios tend to increase during times of stress, thus increasing portfolio risk and reducing diversifica-

${ }^{3}$ IBM and the World Bank entered into the first currency swap in 1981, and the US Student Loan Marketing Association ("Sallie Mae") launched the interest rate swap market in 1982. The International Swaps and Derivatives Association published the first edition of its Swap Code in 1985, and the prototype Master Agreement in 1987.

${ }^{4}$ However, 18th century Dutch merchant bankers sold securities backed by pools of mortgage loans to West Indian plantation owners (Goetzmann and Rouwenhorst, 2008). Also, US mortgage companies issued debentures backed by farm mortgages in the late 19th century, and commercial and residential mortgages in the 1920s (Snowdon 2007; White 2009). 
Figure 3.1. Outstanding Over=the-Counter Derivatives

(Trillions of US dollars notional)

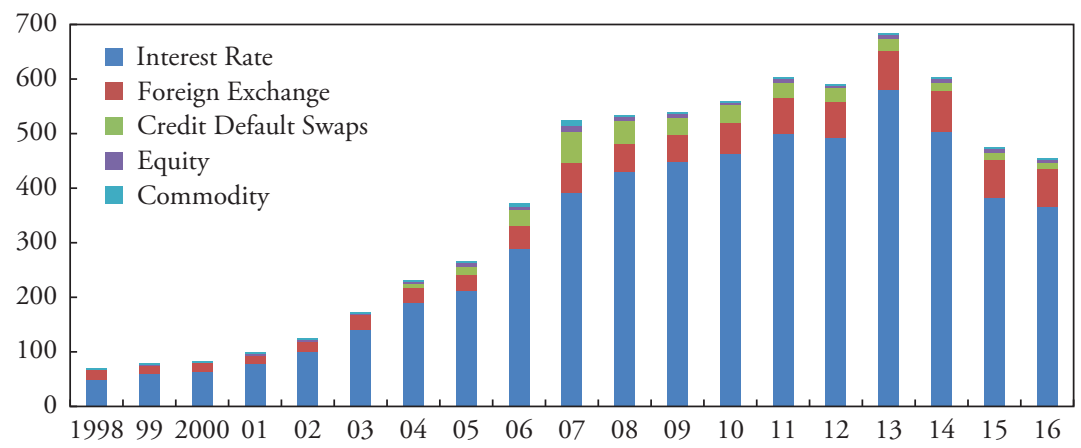

Source: Bank of International Settlements.

tion effects. Furthermore, common implementations of Li's calculations are based on Gaussian copulas and do not feature fat return tails during financial turbulence. While the shortcomings of Li's approach to securitization portfolios was recognized early on, the systemic implications of many firms adopting such risk management strategies went unrecognized until the 2008 global financial crisis, when CDOs and correlation books underperformed markedly relative to the underlying model assumptions.

Figure 3.2a. US Private-Label Term Securitization Issuance by Type (Billions of US dollars)

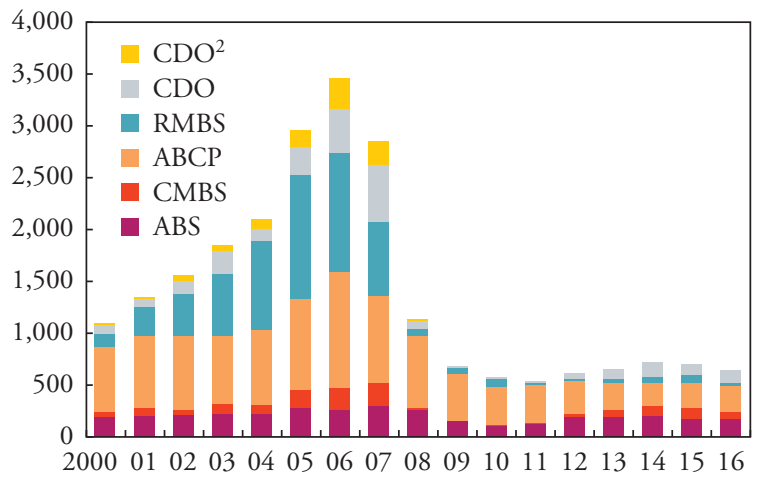

Sources: Estimates based on data from JPMorgan Chase \& Co., Board of Governors of the Federal Reserve Systems, the CRE Finance Council, Inside Mortgage Finance, and the Securities Industry and Financial Markets Association.

Note: $\mathrm{ABCP}=$ asset-backed commercial paper; $\mathrm{ABS}=$ asset-backed securities; $\mathrm{CDO}=$ collateralized debt obligation; $\mathrm{CDO}^{2}=$ CDO-squared \& CDOs backed by ABS \& MBS; CMBS = commercial MBS; MBS = mortgage-backed securities; RMBS = residential MBS.
Figure 3.2b. European Private-Label Term Securitization Issuance by Type

(Billions of US dollars including retained issuance)

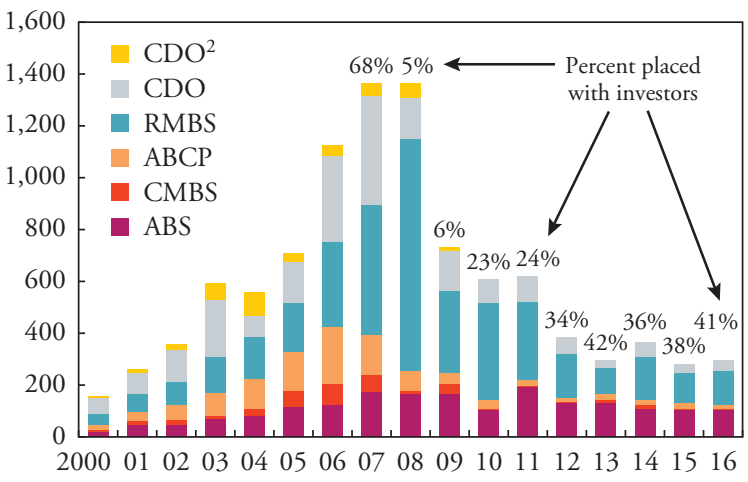

Sources: Estimates based on data from Fitch Ratings, JPMorgan Chase \& Co., Merrill Lynch, the CRE Finance Council, and the Association for Financial Markets in Europe.

Note: $\mathrm{ABS}=$ asset-backed securities; $\mathrm{CDO}=$ collateralized debt obligation; $\mathrm{CDO}^{2}=\mathrm{CDO}$-squared and $\mathrm{CDO}$ s backed by $\mathrm{ABS}$ and MBS; CMBS = commercial MBS; MBS = mortgage-backed securities; RMBS = residential MBS. 
Figure 3.3. Ratings of AAA-Rated US RMBS-Related Securities (Percent of S\&P originally rated 2005-07 issuance as of July 31, 2010)

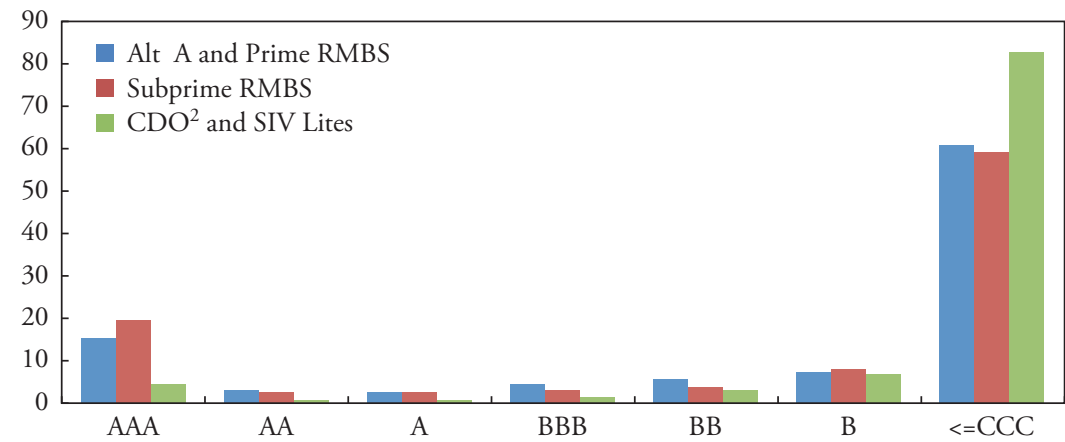

Sources: Estimates based on data from S\&P, JPMorgan Chase \& Co., Board of Governors of the Federal Reserve Systems, the CRE Finance Council, Inside Mortgage Finance, and the Securities Industry and Financial Markets Association.

Note: $\mathrm{CDO}=$ collateralized debt obligation $; \mathrm{CDO} 2=\mathrm{CDO}$-squared $\&$ CDOs backed by $\mathrm{ABS}$ \& MBS; RMBS = residential mortgage-backed security. This figure shows the proportion of US RMBS-related securities from 2005 to the end of 2007 rated AAA, AA, A, etc. on July 31, 2010, when S\&P stopped publishing the data.

\section{Real-World Challenges}

Despite rapid technological and intellectual progress, the evolution of risk management practices has often been motivated by events. For example, important lessons were learned from the 1998 Long-Term Capital Management (LTCM) collapse and 2008 financial crisis. In both cases, there was inappropriate risk management model parameterization (correlation, liquidity, and counterparty risk), and in the case of the crisis, mechanical overreliance on credit ratings, and model misspecification. These shortcomings in conceptual approaches were compounded by weak internal controls, allowing traders to exploit any shortcomings in risk management techniques on a broad scale.

LTCM estimated VaR inputs using then-recent low volatility historical data, and assuming future returns would be normally distributed (Jorion 2006). Financial time series tend to have fatter tails than normal distributions. Furthermore, some of the credit-sensitive instruments that LTCM focused on exhibit asymmetric profit and loss distributions. In addition, LTCM's risk models made market liquidity assumptions that were heroic given the massive size of their positions.

Until early 2005, American International Group's (AIG’s) guaranteed financial products subsidiary sold massive amounts of RMBS default protection to systemically important banks. It could avoid posting collateral because both AIG and the RMBS were rated AAA. After AIG was downgraded to AA+ in March 2005, it had to start posting margin collateral. As the 2008 crisis 
unfolded, AIG's mounting collateral posting requirements, coupled with liquidity strains from its securities lending unit, became unsustainable. Getting default correlation assumptions right is one of the key challenges for evaluating the risk of CDOs, and decisive for credit rating accuracy. Differences in correlation assumptions and modeling approaches can potentially lead to meaningful differences in CDO risk metrics and ratings. This model risk was not well understood by investors, and those who did underestimated loan default correlations, which resulted in massive underestimation of the default risk of senior CDO tranches.

Figure 3.3 shows that over three-quarters of all private-label RMBS issued in the United States from 2005 to 2007 that were originally rated AAA by Standard \& Poor's were rated below BBB- by 2010, clearly a sign of model failure. 


\section{ChAPTER}

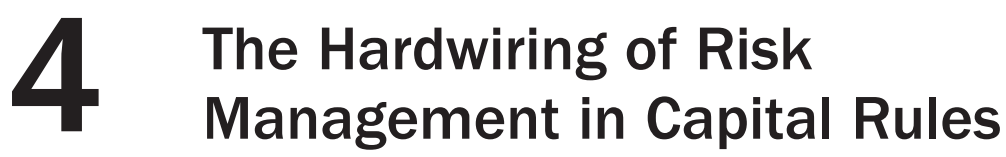

"The proposed regulations fail to consider the fact that risk is endogenous." (An Academic Response to Basel II)

The Basel Committee had started working on the inclusion of market risk in the capital framework "in earnest" following the finalization of the Capital Accord in July 1988, recognizing that "banks' trading activities were expanding rapidly, particularly in the derivatives market" (BCBS 2012).

The financial disturbances related to the 1987 US stock market crash had certainly contributed to the committee's motivation to expand the capital framework's coverage beyond the banking book to the trading book; episodes like the Salomon Brothers' Treasury auction scandal and the blowup of Drexel Burnham Lambert had further evidenced the kind of abuses that unregulated or lightly regulated trading activity could engender. This challenged the traditional view (prevalent in the United States, at that time) that investment banks do not pose systemic risk and highlighted the need for consolidated regulation and supervision to prevent problems at the (unregulated) conglomerate level from spreading to regulated entities within the group.

In 1996 an amendment to Basel I introduced capital requirements for market risk: recognizing the banks' progress in risk measurement, regulators introduced-for the first time- the option for banks to use their own models to calculate capital requirements.

The innovation was in line with the then-prevailing idea of market-friendly regulation and of "incentive compatibility," that is, that a regulation more aligned with bankers' own incentives (supposedly those of accurately measuring and actively managing risks) would reduce the supervised entities' resistance to following the rules and would trigger, instead, a vir- 
tuous and self-reinforcing convergence between the banks' and regulators' views on risks.

The market risk rules were closely modeled after existing risk management practices. Use of portfolio models was allowed in full (unlike for credit risk, later on, under Basel II): banks would calculate their capital requirements directly from their VaR models (though subject to a multiplier), provided these had been vetted by regulators and found compliant with a series of qualitative and quantitative requirements.

This development was welcomed by the industry. Of course, with the benefit of hindsight, the adoption of firms' internal VaR models raises legitimate questions about the regulatory community's overall wisdom and good judgment. In this regard, it must be said that, even at the time of the Market Risk Amendment, the Basel Committee was well aware that "relying on banks' internal systems as a basis for capital charges creates dangers of its own" and, for this reason, it proposed safeguards designed to minimize the risk of abuse. ${ }^{1}$ Market risk thus entered the capital framework with the potential of considerably increasing its risk sensitivity, but also sowed the seeds of a dilemma that has characterized the evolution of banking regulation since: the dilemma between risk sensitivity and cyclicality.

A more risk-sensitive capital framework might be desirable from a "cross-section" perspective because of its better alignment (as mentioned above) with the banks' own perception of the risks they incur and for the mitigation the framework provides against adverse selection (the tendency, under a risk-insensitive rule, for less risky but overcapitalized deals to be crowded out by riskier and undercapitalized ones). But it comes at a price from a dynamic, time-dimension perspective: capital requirements will tend to be low when market volatility is low and to increase when volatility spikes, trailing events instead of anticipating them.

The result can be a lack of any built-in restraint in the boom phase, when risks are perceived as low but might be building up undetected; and, on the contrary, an automatic increase in capital requirements when risks materialize. This is likely be compounded by any losses, liquidity strains, and funding difficulties a bank might be experiencing (together with a lack of earnings to retain and/or increased difficulty in raising more capital).

Worse, volatility itself depends on the behavior of market participants. In booms, when asset prices rise and risk tends to be moderate, VaR constraints are loose, allowing unusually strong risk taking. In the aggregate, such behavior by financial institutions will lead to further valuation pressures and fur-

${ }^{1}$ Basel Committee's Market Task Force, in Goodhart (2011). 
ther compression of market volatility. Such a positive feedback loop not only works on the upside, it also amplifies adverse shocks: financial institutions' $\mathrm{VaR}$ constraints start binding and they have to sell assets, putting downward pressure on prices and pushing up market volatility. Hence the pricing of risk, and market risk itself, is a function of the fact that institutions use short-term VaR measures. ${ }^{2}$

By the late 1990s the improvements in market risk management had spread to other fields, in particular to credit risk portfolio models. The re-engineering of credit risk measurement and management along the lines already tracked by market risk managers needed to adequately address the most important differences between the two types of risk in terms of (1) time horizons (short for market risk versus medium-long for credit risk), (2) accounting (mark-to-market versus accrual), (3) tradability (tradable versus typically nontradable), (4) data availability (frequent versus rare events), (5) organization (typically centralized versus decentralized), and (6) skills (focused and highly specialistic versus wide and diversified). The awareness of these differences guided the Basel Committee in its effort to make its rules for credit risk more sensitive to the different risk types: for example, full portfolio modeling (that is, direct calculation of capital requirements out of banks' credit VaR models) was avoided, in recognition of the far more challenging task of modeling dependency between untraded credit risk exposures.

The solution adopted by the committee consisted of allowing banks that were perceived to be adequately advanced and sophisticated to assign ratings to their exposures and to estimate probabilities of default associated with those ratings and loss given default (LGD) associated with the exposures' characteristics. The transformation of these inputs into capital requirements was engineered within the regulation (Internal Ratings Based formulas), building on Vašíček’s loan portfolio value model.

The general prevalence of credit risk in banks' balance sheets meant that this expansion of risk sensitivity beyond the trading book also led to an amplification of the procyclicality issue, as pointed out by some academics early on (Danielsson and others 2001), and others subsequently (Kashyap and Stein 2004; Repullo and Suarez 2008; among others).

The problems highlighted in the case of market risk rules are exacerbated, in the case of credit risk, by the more intense feedback loop with the real economy: banks that incur larger losses and higher capital requirements while experiencing negative income and limited access to capital markets-

\footnotetext{
${ }^{2}$ Adrian and Shin (2010) document these dynamics empirically, Adrian and Shin (2014) provide a microfoundation for $\mathrm{VaR}$, and Adrian and Boyarchenko (2016) show the procyclicality that is induced by VaR risk management in an equilibrium macroeconomic model.
} 
as is likely to be the case in downturn conditions - might find themselves collectively obliged to cut lending. This could compromise the financial soundness of their obligors and further exacerbate problems in their own loan portfolios.

Addressing the procyclicality issue has been framed as a matter of adjusting the inputs (ratings and/or risk parameters), the outputs (capital requirement), or the relationship between the two (IRB formula) (Gordy and Howells 2006). On the path to Basel II, the debate leaned decisively toward the first type of solution, and the framework eventually embraced an orientation favorable to so-called through-the-cycle ratings and risk parameters (as opposed to so-called point-in-time ones): banks were required to rate their obligors according to their expected creditworthiness through different phases of the business cycle and to estimate risk parameters in a way to incorporate bottom-of-the-cycle conditions (for example, "downturn” LGD).

This was neither aligned with banks' practices, which tended to rely mainly on point-in-time ratings for a number of internal applications (for example, monitoring, renewal, risk-adjusted performance measurement), nor effectively enforceable, as full understanding of its implications for rating assignment and risk parameter estimation was limited not only among practitioners, but also among regulators. ${ }^{3}$ Ultimately, however, only forward-looking stress testing introduced after the 2008 financial crisis and the introduction of a leverage ratio in Basel III addressed procyclicality head-on.

Banks not eligible for the IRB approach (either for lack of internal models or for missing the regulatory conditions for their approval) were required to apply a standardized approach to credit risk. With respect to the Basel I rules, the approach innovated in terms of use of external (rating agencies') ratings as risk weights' determinants and more granular and risk-sensitive recognition of credit risk mitigation techniques.

The use of external ratings, which had been first introduced with the market risk amendment in 1996, put rating agencies at the core of regulation. This was already criticized at the time of the proposal-and even more so in the aftermath of the global financial crisis-for the extreme reliance put on the assessments produced by lightly regulated rating agencies operating in an oligopolistic context fraught with conflicts of interest. ${ }^{4}$

${ }^{3}$ Changes to the framework introduced after the global financial crisis tend to rely more on adjusting the output.

${ }^{4}$ While criticism of the excessive reliance on external ratings has generally been widespread, it must be pointed out that the majority of the problems that became evident during and after the crisis related mostly to the recently established rating of structured products (for example, asset-backed securities) rather than the more consolidated rating of corporate bonds. 
In the United States, the major independent broker dealers (that is, the five largest investment banks) were subject to consolidated supervision by the U.S. Securities and Exchange Commission (SEC) under Basel II rules. This followed an SEC decision to supervise the parent holding companies of the largest investment banks (previously it regulated directly only their broker-dealer units).

It is debatable whether the following rapid expansion of these banks' activity was a consequence of the application of commercial banks' rules (with their built-in preferential treatments for residential mortgages and instruments based on residential mortgages) or of the SEC letting securities firms increase their risk taking sharply. ${ }^{5}$ In either case, a flawed regulatory initiative seems to have contributed to igniting one of the main engines of the subsequent fallout in financial markets.

In terms of accounting treatment, the Basel II framework largely took local accounting rules as a given, with no or minimal adjustments. For credit risk, under the standardized approach, loss provisions are deducted from gross exposures before applying the due risk weight. Under the IRB approach, a comparison is made between total expected losses and total eligible provisions, with the difference between the two-if positive-totally deducted from capital or - if negative-partially recognized as supplementary capital. For market risk, valuation adjustments/reserves must be made in the trading book to account for a series of factors not necessarily captured under prevalent accounting rules (including model risk).

This lack of (or mild) interference with accounting rules was considered, at the time, an appropriate reflection of the different spheres of influence of accounting versus prudential rules. But the boundary looked increasingly blurred and evidenced the contrast between conflicting priorities on loan loss reserves. Accountants expected to be guided by the principles of financial statement objectivity and comparability, while supervisors saw mainly through the lens of bank solvency over the credit cycle (Balla and Rose 2012). This potential conflict had emerged clearly in the United States in the late 1990s, when, possibly as a result of an SEC inquiry about the overstatement of loan loss reserves by SunTrust, a reduction was observed in the provisioning of publicly listed banks (subject to the SEC's purview) as opposed to privately owned banks (Balla and Rose 2012). The partial fixes under the IRB approach of Basel II did soothe the regulators' concerns about bank provisions' adequacy, but only up to a point. A stronger convergence between accounting and prudential rules occurred only as a reaction to the serious flaws of the incurred-loss approach evidenced by the crisis. 



\section{Chapter}

\section{The Crisis of 2008}

"When the music stops, in terms of liquidity, things will be complicated. But as long as the music is playing, you've got to get up and dance. We're still dancing." (Chuck Prince, CEO of Citibank)

The 2008 crisis uncovered massive failures of risk management, both at the individual firm level and at the system level by regulators. Although it was triggered by the collapse of the US housing bubble, its severity was amplified by risk management model misspecifications and overreliance on credit ratings by banks, investors, and regulators. The crisis also uncovered huge data gaps at all levels, from public disclosures to supervisory surveillance.

\section{Building Blocks}

The years before the crisis witnessed a widespread, collective underappreciation of the buildup of risks across the global financial system. The global economic environment appeared benign, with many commentators talking of the "Great Moderation" or "Great Stability." Inflation was generally low and stable, while strong economic growth reduced unemployment to low levels.

Global imbalances were nonetheless high. A substantial buildup of savings in Asia (national savings rates in China topped 50 percent of GDP) flowed back to the West, pushing down interest rates and fueling a massive search for yield as investors sought to raise returns by taking on higher-risk instruments, such as subprime debt and complex structured products (Bernanke 2005). Risk premiums were bid down to low levels, as investors took comfort from the apparently benign market conditions. Although there was increasing recognition that risks were rising, many market participants took the view that the gains from continuing to participate actively outweighed the likely costs 
should risks crystallize and the music stop. Short-term performance targets encouraged this view.

Financial intermediation grew rapidly in advance of the crisis, spurred by deregulation and global capital market integration, financial innovation, and the perception of a sustainable, benign macroeconomic outlook. Costs of intermediation, such as bid-offer spreads or credit spreads on standardized instruments, fell sharply. BIS data show the outstanding value of interest rate swaps and other derivatives reached almost $\$ 600$ trillion, or some 11 times annual global GDP, by the end of 2007 . Ten years previously, the value was about $\$ 75$ trillion ( $2 \frac{1}{2} 2$ times global GDP). In 2007 alone, the global derivatives market expanded almost 50 percent. The outstanding value of credit default swap (CDS) contracts surged to more than five times the outstanding principal of global corporate bonds by the end of 2007. Yet just three years earlier, the CDS market was only some 85 percent of the size of the corporate bond market. Issuance of asset-backed securities globally was $\$ 1,460$ billion in the first half of 2007, up from $\$ 425$ billion nine years before. There was rapid expansion in the market for CDOs, from $\$ 75$ billion in the first half of 2005 to $\$ 200$ billion in the first half of 2007 .

One of the root causes was the growth of "originate to distribute" lending models that transferred banks' credit risk to capital markets via securitization. The going assumption was that securitization dispersed banks' credit risk to broad and diverse groups of investors with differing risk management and investment objectives, including other banks seeking portfolio diversification. This was thought to provide more consistent credit provision, and improved financial system resilience (Geithner 2006; IMF 2006).

Securitization also allowed banks to reduce capital requirements - the capital requirements on bank securitization products were typically much lower than what they would be on the pool of underlying loans. For example, the capital requirement on the senior tranche of a typical subprime mortgage-backed security, which comprised up to 85 percent of the total face value of the underlying loans, could be less than 1 percent of the nominal value. ${ }^{1}$

The lower capital requirements were driven by risk models (both in the credit rating agencies and in IRB banks) that gave such senior tranches the highest investment-grade credit ratings. This reflected the loss protection provided by the less senior tranches and other structural features. ${ }^{2}$ The same principles

${ }^{1}$ Under the Basel II standardized approach, a top-rated securitization product tranche is subject to a 20 percent risk weight versus 35 percent or higher on the underlying mortgage loans. On highly leveraged loans, the risk weight can be as high as 100 percent in some jurisdictions. Under the IRB approach, the risk weight could be as low as 7 percent, leading to a capital charge of as low as 0.56 percent.

${ }^{2}$ The securitization process repackages pools of loans into securities for transfer to third parties, after which structured finance techniques divide the cash flows into tranches. Tranche holders are paid in a specific order, 
applied to securitization products backed by other assets such as commercial mortgages, leveraged loans, and corporate bonds. Driven by the low capital requirements and the perceived safety of these securities, issuance volumes soared from 2002 to 2007.

Two other popular investment bank strategies involved selling securitization products to special purpose entities (SPEs). The SPEs funded the purchases by issuing $\mathrm{CDO}$ s or asset-backed commercial paper (ABCP). Thanks to the application of the same structuring techniques applied to the underlying securitization products, plus performance guarantees by the sponsoring banks, these resecuritization products were also given the highest investment-grade ratings (see Figures 3.2a and 3.2b).

However, the performance guarantees undermined the original point of the underlying securitization transactions by transferring the credit risk back to bank balance sheets. Furthermore, the guarantees could be structured as liquidity facilities available only "in the event of a general market disruption," on which there were no regulatory capital requirements. ${ }^{3}$ This not only allowed banks to further leverage their balance sheets, it also lengthened intermediation chains and increased the complexity and interconnectedness of the financial system (Figure 5.1). And notwithstanding the rapid growth of structured products and of the originate to distribute model, many banks also sharply expanded their balance sheets, relying increasingly on short-term wholesale funding to finance increased lending and holding of securitized instruments.

This changing structure of intermediation increased the potential for disruptions to spread swiftly across markets and borders, and gave rise to severe principal/agent problems (Ashcraft and Schuermann 2008). As risks were passed along the chain, those best placed to maintain prudent loan underwriting and monitoring standards were more focused on fee maximization. Demand for these products was facilitated by the high credit ratings, and the outsourcing of appropriate due diligence by many end-investors.

Rating agencies also faced incentive conflicts, as an increasing share of their income came from the issuers that dominated the securitization business.

starting with the "senior" tranches (least risky) working down through various levels to the "equity" tranche (most risky). If some of the expected cash flows are not forthcoming (for example, if some loans default), then, after any cash flow buffers are depleted, the payments to the equity tranche are reduced. If the equity tranche is depleted, then payments to the "mezzanine" tranche holders are reduced, and so on up to the senior tranches. See Ashcraft and Schuermann (2008) for more detail.

${ }^{3}$ Basel II specified "eligible liquidity facilities that are only available in the event of a general market disruption (that is, whereupon more than one SPE [Special Purpose Entity] across different transactions are unable to roll over maturing commercial paper, and that inability is not the result of an impairment in the SPEs' credit quality or in the credit quality of the underlying exposures)" (BCBS 2009, page 8). 
Figure 5.1. Intermediation Chain Lengthening

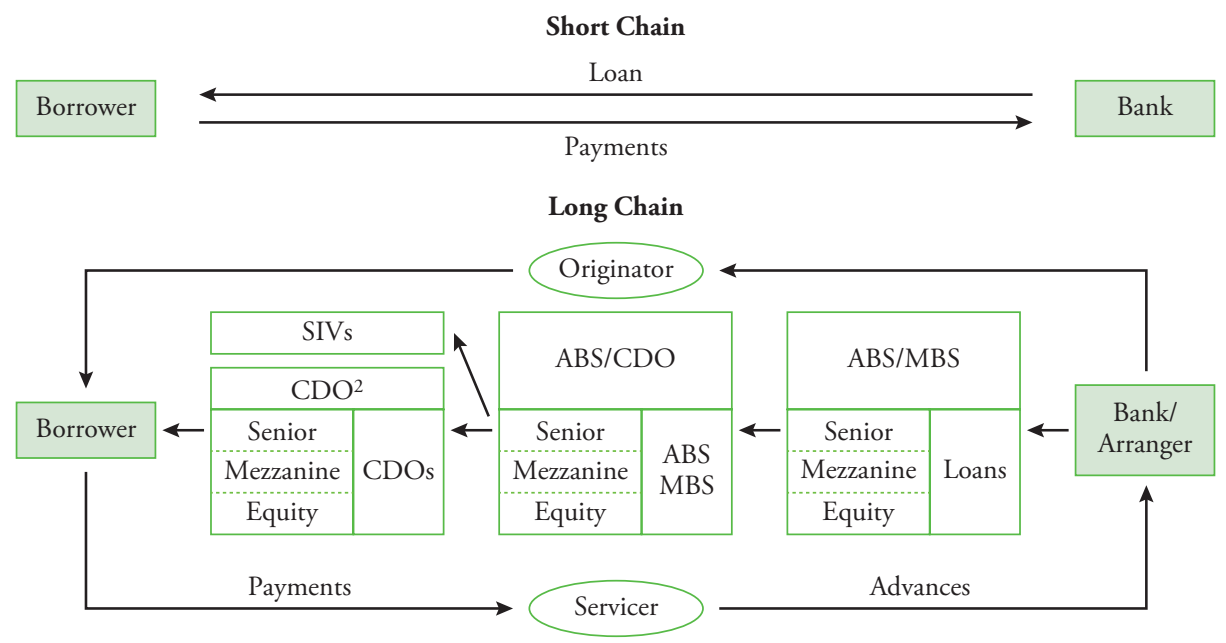

Source: Figure 2.11 in IMF (2009).

Note: $\mathrm{ABS}=$ asset-backed securities; $\mathrm{CDO}=$ collateralized debt obligation; $\mathrm{CDO}^{2}=$ collateralized debt

obligation squared; $\mathrm{MBS}=$ mortgage-backed securities; $\mathrm{SIV}=$ structured investment vehicle.

These issuers figured out how to game the rating agency criteria, and were perceived to be receiving structuring advice from the rating agencies. In any case, flawed methodologies and data inputs were often used to assign ratings, and the investors who relied on them did not always have access to sufficient information to question and assess them.

The methodologies and inputs used to rate nonprime MBS and CDOs backed by MBS were particularly flawed, overestimating the quality of the underlying loans and underestimating the correlation of their performance. Also, investors did not account for the fact that structured credit products are likely to suffer more severe, multiple-notch downgrades relative to the typically smoother downgrade paths of corporate bonds.

In addition, accounting standards allowed institutions to be less than transparent about their exposures to securitization products. They allowed securitization risk exposures to be hidden from investors and regulators in SPEs and $\mathrm{ABCP}$ conduits. Also, products held by banks for trading purposes ("intended for sale before maturity") were subject to fair market valuation, but when observable market prices were unavailable, valuations could be based on nontransparent theoretical models.

The fragility of the system was further increased by the short-term vehicles funding these operations, such as ABCP conduits, money market mutual funds (MMMFs), and sale and repurchase agreements (repos). The system was dependent on $\mathrm{ABCP}$ and repo rollovers, and vulnerable to MMMF runs. 
Plus, repo market capacity was dependent on the maintenance of collateral values, and haircut levels (the higher the collateral value and/or the lower the haircut, the higher the capacity). ${ }^{4}$

At the same time, there was a paucity of data available for authorities to quantitatively assess the size of these markets and the degree of risk reduction among banks, or to monitor where credit risks had gone. Submitting OTC derivatives transactions to trade repositories was voluntary, and the information collected was of limited use to the authorities. Sizing repo markets depended on occasional surveys by authorities and industry bodies.

\section{Perfect Storm}

The 2008 crisis was triggered by flattening US house price appreciation and a collapse of the mortgage securitization market. Prior to the crisis, US housing affordability had dropped to the point where significant numbers of borrowers were financially overstretching via "affordability" products, with many misreporting their financial resources to get loans. ${ }^{5}$ Also, loans were being made on the basis of expected collateral appreciation, with little account taken of ability to make mortgage payments.

While prices were rising, distressed borrowers had the equity to sell their homes and prepay their mortgages, or refinance their loans and use "cash-outs" to keep up payments. However, as house prices flattened and turned negative, stretched borrowers had to default as prepayment and refinancing options were not feasible with little or no housing equity. As a result, delinquencies and default mortgages soared, despite a benign economic backdrop.

As these losses made their way up RMBS capital structure "waterfalls" and the market value of senior tranches declined, funding markets froze and a shadow bank run commenced. That was on August 9, 2007, when BNP Paribas announced that it was suspending redemptions in three mutual funds

\footnotetext{
${ }^{4}$ It is notable that a sequence of legal changes to the bankruptcy code in the 1980s, 1990s, and 2000s spurred the increased use of derivatives and repos by providing them with safe harbors from automatic stays. Safe harbors allow immediate access to counterparties' posted collateral, whereas most other secured creditors are stayed from enforcing their rights. Also, they can immediately terminate their trades, collect collateral to cover insolvent counterparties' obligations, and become an unsecured creditor on the remainder. This special treatment has been questioned, particularly given financial institution resolution regimes introduced after the 2008 financial crisis (Paech 2016).

${ }^{5}$ Affordability products included "hybrid" and "option" adjustable-rate mortgages requiring interest-only payment at fixed "teaser" rates that can result in negative amortization during the first few years (Kiff and Mills 2007).
} 


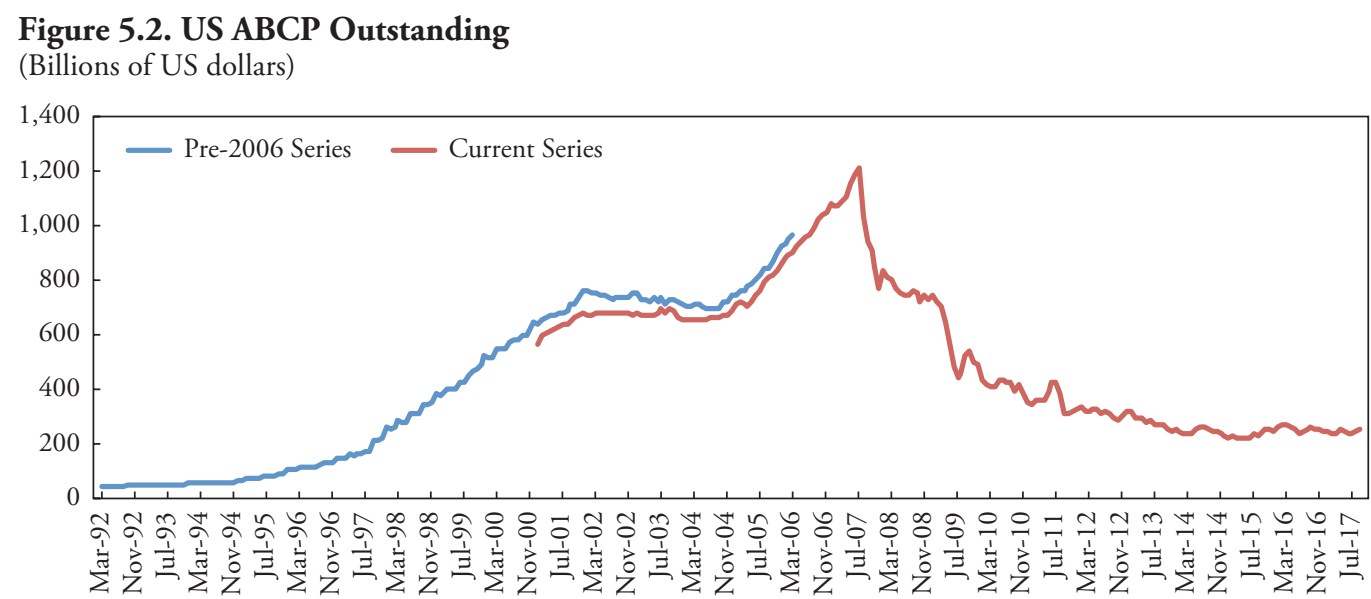

Source: US Federal Reserve.

For background to 2006 change, see https://www.federalreserve.gov/releases/cp/about.htm\#outst_calc.

because it could not value the underlying assets. This was followed by a collapse of ABCP rollovers (Figure 5.2).

Mark-to-market conventions forced lower valuations, which in turn led to fire sales of assets and a self-fulfilling vicious circle of lower valuations, higher volatilities, and larger haircuts (Table 5.1). Opacity and the lack of transparency on exposures to complex, securitized products (and of the inherent value of such products) amplified the selling pressure and defensive behavior of market participants facing uncertain counterparty credit risks. This strained repo markets and put at risk the funding models of investment banks that relied heavily on overnight repo operations for funding. Banks and other market participants began conserving liquidity, drawing down liquidity overseas, cutting back credit lines to counterparties overnight, or ceasing to trade altogether.

The steep contraction in the ABCP also sparked concerns over banks' exposures to their off-balance-sheet vehicles. Several banks brought their ABCP conduit assets on to their balance sheets, creating a significant drain on their liquidity. This general uncertainty further reduced banks' funding access to the capital markets, which fell sharply in the latter part of 2007. Banks that relied primarily on wholesale funding were most vulnerable to the rapidly deteriorating conditions in wholesale funding markets. Some institutions collapsed, such as Northern Rock in the United Kingdom and Bear Stearns and Lehman Brothers in the United States. It is now clear that the institutions that failed, and others that came close, were insufficiently capitalized (Dagher and others 2016). For example, Kapan and Minoiu (2017) find that banks with stronger balance sheets and higher levels of common equity were better able to cope with liquidity shocks during the crisis, including having access to lower costs of funds. 
The insurance sector did not escape unscathed: for AIG, two massive mortgage-related securities "carry trades" led to its near failure (McDonald and Paulson 2015). The ultimate losses were $\$ 30$ billion from selling credit protection on CDOs and $\$ 21$ billion from using its securities lending book to repo high-rated insurance company assets against higher-yielding CDOs and RMBS. These bets were driven by the belief that the underlying AAA-rated mortgage-related securities would be "money good" in the long term, and that security markets would stay liquid. AIG exposed itself to catastrophic liquidity and housing market risks, which ultimately led to its undoing. ${ }^{6}$

${ }^{6}$ McDonald and Paulson (2015) show in fact that the "money good" assumption turned out to be grossly erroneous. 


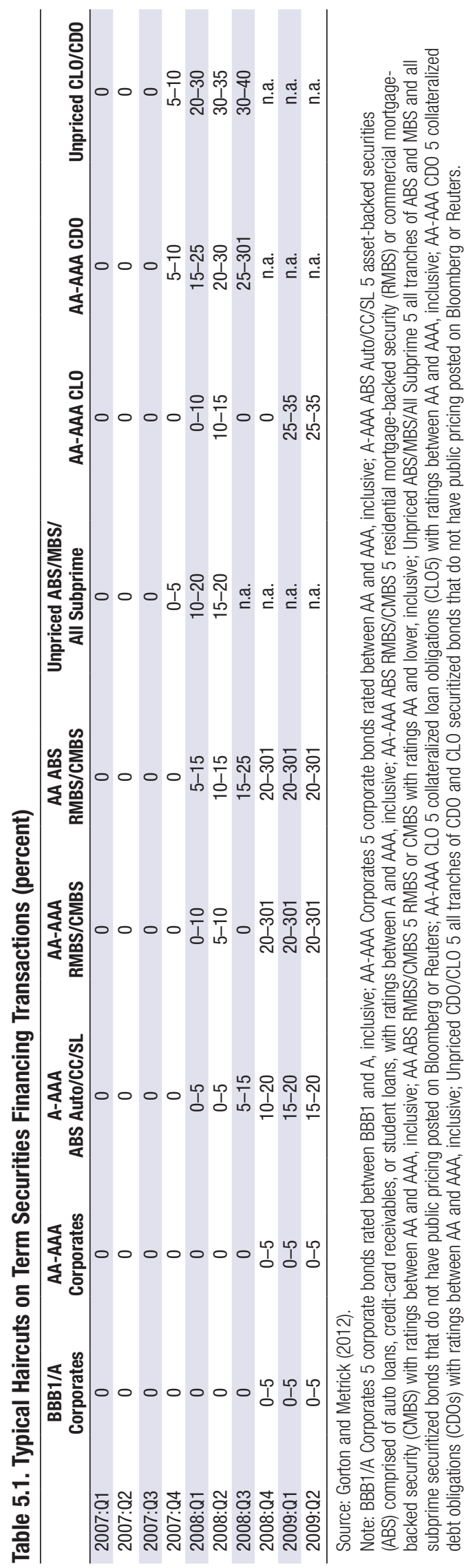




\section{Chapter}

\section{(6) Postcrisis Regulatory Innovations}

"A well-capitalized banking system is essential for the revival of the credit flows that will underpin a sustainable economic recovery." (Ben S. Bernanke, May 2009)

The crisis revealed many weaknesses and fault lines in financial regulation and supervision as well as major deficiencies in firms' risk management systems. Over the past 10 years, members of the global financial regulatory community have worked together to develop and implement a major reform program to correct the identified fault lines. The program is nearing completion. The overarching aim has been to build a more robust and resilient global financial system that can continue to support the real economy in times of stress. The program has been driven and coordinated at the global level by the Financial Stability Board and international standard-setting bodies such as the Basel Committee on Banking Supervision (BCBS), International Association of Insurance Supervisors (IAIS), International Organization of Securities Commissions (IOSCO), Committee on Payments and Market Infrastructures (CPMI).

The reforms can be grouped into four main elements:

1. Measures to strengthen the system-wide focus of financial policymaking and supervision;

2. Initiatives designed to contain the buildup of risks in the financial system;

3. Policies to improve the resilience of the financial system in the event of stress; and

4. Reforms to contain moral hazard and lower the costs of handling failure. 


\section{Strengthening the System-Wide Dimension}

One of the major lessons of the crisis is the need to focus much more attention on the financial sector as a system, recognizing the importance of collective behavior and of the close interconnections and interactions across the financial network. As one example, investors in complex, structured products mistook benign market conditions as an indicator that they would be able to exit positions quickly in the event of an adverse shock. They failed to recognize that there was a concentration of risk and that all other investors were likely to wish to exit their positions at the same time, leading to an evaporation of market liquidity - in the worst case, completely-and thus to a major write-down of value. As another example, many banks had liquidity contingency plans that relied on defenses such as liquefying illiquid assets, bidding for additional deposits, or restricting balance sheet size. If the bank in question was the only one facing stress and overall market conditions were normal, then such plans might work well. But in the event that other banks faced similar strains, for example, as a result of increased concern about the quality of their loan book and potential exposure to subprime mortgages, then such defenses would no longer work-indeed they would tend to exacerbate system-wide stress. A third example is the reliance of many European banks on a steady rollover of short-term wholesale dollar funding from US money market funds. This motivated the creation of the Term Auction Facility, where foreign banks were the major borrowers of term money at the Federal Reserve's discount window.

These examples (and many more) highlight the importance of taking a strong system-wide perspective, both in the assessment of risk and in the design and implementation of financial regulation. That is a necessary complement to strong supervision of individual banks. In terms of risk assessment, more attention is now paid by authorities to the assessment of potential systemic risks that could impair the financial system and disrupt the provision of financial services. System-wide risk assessments require much more attention to the buildup of leverage, and of common exposures and concentrated risks through interconnections and interlinkages. In terms of regulatory design, it is important that the framework helps to contain the rise of system-wide risk and that if the risk crystallizes, the defenses can be used without creating major externalities and spillovers elsewhere in the system.

Many countries have introduced new institutional macroprudential frameworks to strengthen the oversight and containment of systemic risks-a process welcomed and strongly supported by the IMF (2011, 2013, 2014). Considerable analytical and policy work has been undertaken to help support the design and implementation of effective macroprudential policies (IMF 2014; IMF, FSB, and BIS 2016) and to ensure that financial regu- 
lation takes into account the precept of protecting the functioning of the system as a whole.

\section{Initiatives to Contain the Buildup of Risks}

A framework to contain the buildup of systemic risks must take account of both longitudinal and cross-sectional dimensions. The longitudinal element should focus on dampening the inherent procyclicality in the financial system. It requires tools that help to contain the rise of system-wide risks in the upswing, which stem from incentives to overextend leverage and credit and to build up risk concentrations and push up asset prices beyond fundamentals, and to protect the system in the downswing when these forces move into reverse. The cross-sectional elements aim to improve the resilience of the system to failure of an institution at any point in time, in particular, what measures can and should be taken to contain spillover and contagion in such an event.

One of the measures to strengthen the longitudinal element is the introduction by the Basel Committee of a countercyclical buffer in the banking system-supervisory authorities requiring banks to hold additional capital at times of excessive credit growth that can be released in a subsequent downswing to cushion deleveraging. Of course, the effectiveness of the countercyclical capital buffer requires regulators with foresight-history will tell how effective the application of the tool proves. Strengthened monitoring has also led to more active application of a range of other policies and tools to contain sources of potential systemic risk. Common examples are instruments applied in real estate markets through loan-to-value and debt-to-income constraints, or in corporate lending markets through risk weighting. In addition, a capital conservation buffer that can be run down during times of stress counteracts procyclicality.

Perhaps more important, forward-looking stress tests that have been introduced in the supervisory processes of many jurisdictions directly counteract procyclicality, as they condition on severe stress scenarios many months into the future. That means that risk assessments in those tests are forward looking, requiring institutions to hold more capital when risks are building. Hence these types of stress tests hardwire an assumption of an extreme form of portfolio illiquidity into the behavioral assumption, overcoming one of the main shortcomings of the VaR methodology. Of course, the severity of stress assumptions needs to be adequate to generate correct levels of capital. The IMF pioneered these types of stress tests starting with the first Financial 
Sector Assessment Program in 2000, and they were widely adopted by supervisors following the 2008 crisis. $^{1}$

Strengthening the cross-sectional dimension of financial regulation entails close attention to the question of how the design of regulation should take account of an institution's contribution to systemic risk. New analytical tools have been developed to support such an assessment (such as CoVaR) (Adrian and Brunnermeier 2016). And policymakers have implemented new regulatory tools such as systemic capital surcharges (and in some cases, other supplementary regulatory instruments) for global (and domestic) systemically important banks, as well as more intrusive and intense supervision, to address the externalities posed by such institutions. Additional steps have also been taken to contain the buildup of network or interconnectedness risks, for example, through a toughening of large exposure rules (with stronger constraints on exposures between systemically important banks) and measures to mitigate potential spillovers between the banking system and the shadow banking system.

Measures have also been taken to address misaligned incentives that supported a buildup of systemic risk in advance of the global financial crisis. As one example, new compensation principles have been agreed to by the Financial Stability Board to improve the alignment of compensation with risk taking by requiring the compensation package for principal risk takers to contain a high, variable component that is deferred and remains at risk depending on realized performance (FSB 2009a, 2009b). A second example is that new guidelines on securitization have been agreed to, including a requirement for the originator to retain a proportion of the risk (IOSCO 2012). A third example is steps taken to encourage greater risk assessment by market participants by reducing mechanistic reliance on rating agencies (FSB 2012).

\section{Policies to Improve the Resilience to Stress}

Reforms to strengthen the resilience of the banking system to stress are the centerpiece of the reform program. At the heart of the reforms is the Basel III initiative to raise the quality and quantity of bank capital and to provide a much stronger and resilient sector in the event of stress (BCBS 2011). Furthermore, the leverage ratio is a backstop that counteracts the procyclicality of risk-based capital requirements. Work is continuing to finalize the approach to addressing the observed excessive variability of risk weights. The revised Basel framework also contains important new international standards for liquidity risk for the first time, as well as enhanced approaches for market risk and operational risk. Elements of the framework have been specifically designed to support resilience, for example, the requirement for a higher proportion of loss-absorbing

${ }^{1}$ See Ong (2014). 
common equity than was the case in Basel II. There is also a capital conservation buffer that supports supervisors and banks in strengthening the financial position of weak banks through the constraints associated with the buffer's use.

In parallel to the strengthening of regulation, many supervisory authorities now place additional reliance on enhanced stress tests to underpin their assessment of capital and liquidity plans. Stress tests are an integral part of the risk management and supervisory toolkit, enabling banks and supervisors to identify areas of potential vulnerability and weakness in a forward-looking context, and to support the formulation of plans to address them.

Stress-testing techniques have been enhanced significantly in recent years through improvements in analytical models and better data. Stress-testing techniques are also being extended to support systemic risk analysis through models focusing on sectoral contributions to systemic risk, the resilience of nonbank institutions, as well as the robustness of the financial network.

Policy measures have also strengthened the resilience and robustness of financial market infrastructures, which play a pivotal role at the heart of the financial system. Many such infrastructures are systemically important institutions and are thus a major supervisory focus. Policymakers have also introduced policies to support the central clearing of standardized derivative contracts through central counterparties (CCPs), with the aim of lowering bilateral counterparty credit risk. One of the remaining ongoing elements of the reform agenda is to support the robustness and resilience of CCPs and to introduce plans for their recovery and resolution under stress that ensure continued market functioning.

Another main theme of the regulatory reform agenda has been to "transform shadow banking into resilient market-based finance" (FSB 2015). As highlighted earlier, the growth of nonbank vehicles offering bank-like products and susceptible to bank-like risks played a significant role in the buildup to the global crisis. In concert with the sectoral standard-setting bodies and national authorities, the Financial Stability Board has made considerable progress in addressing major risks, for example, by strengthening money market funds, improving securitization markets, lowering interconnectedness between the banking and nonbank sectors, and improving securities financing markets. Work is ongoing to address liquidity and leverage risks in the asset management industry. Notwithstanding this progress, it is vital that authorities continue to monitor the nonbank sector closely, paying special attention to the adaptation of the system and the possibility of new systemic risks emerging beyond the regulatory frontier. 


\section{Containing Moral Hazard and Managing Failure}

Taking additional steps to identify and mitigate emerging risk and bolstering the resilience of the financial system should substantially lower the probability and impact of failures. But the regulatory framework is not aimed at delivering a no-failure regime. Nor should it be. The possibility of failure provides incentives and discipline that strengthen the effective management of financial risks and support the efficiency of financial intermediation.

As failures of financial institutions remain inevitable, the final leg of the reform agenda has thus focused on strengthening crisis management arrangements to support the recovery and, if necessary, enable the orderly resolution of failing firms without major spillovers that would threaten broader financial stability. A clear objective is to eliminate the need for taxpayer support to keep firms afloat because they are seen as too big, too complex, or too interconnected to fail. Such support was a prevalent feature of the crisis, generating moral hazard and the unacceptable privatization of profits and socialization of losses.

Considerable progress has been made internationally to strengthen crisis management arrangements. Special resolution regimes have been introduced in jurisdictions where they were previously absent, and have been enhanced elsewhere in line with new international standards (the FSB Key Attributes ${ }^{2}$ ). To address the specific risks of institutions being perceived as too big to fail, authorities have toughened regulations through a combination of measures. Capital surcharges have been applied where firms are viewed as systemically important and thus impose additional externalities, buttressed by more intensive and intrusive supervision. Major financial institutions are required to introduce explicit recovery and resolution plans, or "living wills," that are subject to supervisory scrutiny and validation. And such arrangements are underpinned in the case of globally systemically important banks by requirements to hold "total loss absorbent capacity" instruments, which can be written down or converted into equity under stress to ensure that critical functions of such banks can be sustained without taxpayer support. Parallel work continues to support the robustness, recovery, and resolution of central counterparties.

\section{Implementation and Evaluation}

The major program of regulatory reform to correct the fault lines at the heart of the crisis is nearing completion. The reform program has been successful in strengthening the financial system and supporting financial stability. And

${ }^{2}$ FSB Key Attributes (2011, updated in 2014). 
there is evidence suggesting that a well-capitalized banking system supports sustainable credit growth (Cohen and Scatigna 2014). It is nonetheless important that authorities carefully evaluate the impact of the substantial changes in financial regulation in response to the crisis, and stand ready to amend policies if major adverse unintended consequences are revealed. Financial regulators also need to closely monitor and adapt to the constant evaluation of the financial system, which poses new risks, opportunities, and challenges. 



\section{Chapter}

\section{Current Challenges}

The experience of the crisis, which brought to light the limitations of what were considered sophisticated quantitative techniques supporting risk measurement and management in preventing or mitigating its impact, has led to introspection on where the line should be drawn between practicality and precision. To many, it suggests that regulation went too far in relying on banks' ability to model their risks and that the attempt to align banks' internal incentives to manage risks and allocate capital with regulation is a bridge too far. It has also led to a worldview that the complexity in the organizational structure, product offerings, and processes and practices of international banks does not lend itself to precision, and that simpler approaches based on supervisory parameters may be safer to rely on. While simpler approaches may be less risk sensitive, these could be easier to implement and hence be better able to be supervised and subject to market discipline.

In light of these concerns, the Basel Committee undertook an effort to simplify the regulatory framework, setting up a task force to balance simplicity, risk sensitivity, and comparability. While direct gains from this introspection may have been limited, one positive outcome of this exercise has been that simplicity is viewed as a desirable goal and no longer as an inferior state of being. This has also mainstreamed the discussions on proportionality, the search for risk-based but less complex regulatory and supervisory standards for firms that are not deemed systemic. At the same time, it has fueled a (mainly) trans-Atlantic discord over the proposed floor, based on supervisory parameters, that seeks to limit the capital relief that can be gained from the application of internal models and hence the variability of risk-weighted assets across firms. Some of the variability can be attributed to differences in national experiences and practices, but there is also some evidence of the active gaming of internal models (Plosser and Santos 2014). While this discord may have political overtones, in essence it represents competing views of regulation emerging post crisis based less on the academic rigor of the under- 
lying risk measurement methodologies and more on supervisory confidence in their implementability and supervisability.

In practice, the challenges faced in implementation and supervision have led to some approaches being revised or abandoned. Regulatory approval for the Advanced Measurement Approaches to Operational Risk is on the verge of being withdrawn due to their complexity, lack of uniformity, and contribution to the variability of risk-weight outcomes across firms. This is despite the fact that the industry has spent over a decade investing time and effort in developing the advanced measurement approaches. The regulatory approach to managing market risks has also been significantly overhauled, first with the introduction of the stressed VaR and then with the Fundamental Review of the Trading Book replacing the VaR methodology with one based on the expected shortfall approach so as to better capture the kind of tail risk events seen during the crisis.

This comes with much more rigorous preconditions for implementation that include separate approvals at the trading desk level and combining regulatory stringency with intrusive supervision. Overall, there has been a considerable erosion of supervisory faith in the ability of banks to use their own models for regulatory purposes, even though it is recognized that diversity in approaches can be useful in countering the herding behavior that can arise from the use of common approaches.

At the same time as the internal modeling approach has been put into question, stress testing has become an ever more central element of the postcrisis approach to supervision. Supervisory stress tests rely on detailed information about the banking and trading books, and combine bottom-up and topdown stress testing. In many jurisdictions, at least for some firms, the stress tests have become the effective constraint on regulatory capital. The complexity of the supervisory stress tests has led to a search for streamlining, which is beginning to be implemented by transforming stress test outcomes into a capital surcharge. This process is beginning in several countries, but might be a promising avenue to make the postcrisis supervisory and regulatory approaches to capital consistent.

While the crisis has led to stronger regulation and intensive supervision across the board, the treatment of sovereign exposures in the regulatory framework remains an area where regulation continues to shy away from adequately recognizing risks. Sovereigns continue to be treated as risk free even though it is widely acknowledged that this treatment can contribute to skewing bank behavior in a manner that can distort risk measurement and put capital at risk. This work did gain ground after the losses held by holders of peripheral European sovereign debt, but has since gone on the back burner. This may indeed be one area where banks are more conservative than their regulators, with some incorporating a less favorable treatment of sovereigns in their risk management frameworks. 
Meanwhile, as the Basel Committee and the FSB struggle to complete the remaining bits of the reform agenda, an often repeated refrain has been that international regulators are too preoccupied in fighting the last war, and that the financial system may be ill prepared for what lies ahead. The response from the policymakers has been that there are important lessons to be learned from the last war, and that it is critical to fix the flaws that became so evident in the crisis and provide a strong degree of assurance about the soundness of the financial system and its ability to withstand the kind of shocks that it succumbed to the last time around. Besides, the fragility of the postcrisis system made it incumbent to extend the implementation period of the reforms over a sufficiently long period. However, everyone acknowledges that looking ahead and preparing for new threats that may be posed by new players and new ways of conducting financial transactions is as much an imperative as is learning lessons from the past.

So how are risk management and regulation likely to evolve in facing the challenges of the future? The rise of financial technology (FinTech) could potentially lead to a redrawing of the boundaries of regulation with the application of innovative technologies to carry out financial transactions more efficiently, but also outside normally regulated financial channels. It has already seen its share of failures, scams, and financial crime, but still holds great promise. Regulations are playing catch-up as they attempt to promote risk management without impeding beneficial innovation. But FinTech can also help their cause, as is held out by the growing use of "RegTech," which supports risk management and regulatory compliance in financial firms, and "SupTech," which can help bring the tools that underlie main FinTech developments (like artificial intelligence, machine learning, and big data analytics) in monitoring, identity management, and data analysis.

But even en route to the future, the challenge of managing the risks posed by the innovative application of technology such as automated trading has already been highlighted in some episodes. Automated trading and its many variants use computer-driven programs to automatically submit bids and offers if certain preset criteria are met, hoping to profit from the spread. The speed of execution and the absence of operators are automatic trading's strength, but can occasionally become a major source of risk, as happened when Knight Capital lost several hundred million dollars within a few minutes, due to a glitch in its algorithm. Such glitches are not just a matter of operational losses by one firm, but can cause market-wide disruptions, as was the case with the March 2010 equity flash crash and the October 2014 Treasury flash rally.

Yet the biggest threat facing the financial system may likely be triggered by a cyber-risk event that has a systemic impact. This may affect the market infrastructures that prevent the timely clearing, payment, or settlement of 
transactions, leading to a liquidity freeze and a waning of trust in transacting through financial channels. Preparing and responding to such an event may prove challenging because the macro-consequences of cyber-related operational risk are not well understood; the collection and sharing of data, whether among firms or supervisors, is hampered by concerns of privacy and reputation; and cross-border cooperation is challenged by the suspicion of state actors being involved that invokes national security considerations.

What are the implications of such scenarios for risk management? The major global banks have been devoting much thought to this, and many now build cyber and operational risks into their stress-testing scenarios as single-factor sensitivity shocks in bottom-up exercises. Supervisors too have started simulating the effect of cyberattacks in their supervisory frameworks. Estimating the buffers needed to guard against cyber-risk losses remains a work in progress and is hampered by the paucity of data relating to actual events. Furthermore, the rapid evolution of technology underlying financial transactions makes historical data a weak predictor of future losses. Until theory catches up with these developments, financial firms will best be served by ensuring stronger focus on developing plans to meet cyber-related contingencies, giving greater prominence to both business continuity planning and the technology function in their risk management architecture. Closer international and cross-sectoral cooperation among supervisors will be a must to promote the sharing of information and to develop global approaches to risk management, as long as the promise of the application of new technologies in finance in dissolving geographical and sectoral boundaries does not become its pitfall. Most important, it is essential to confront these emerging risks on the back of a resilient financial system, hence completing the postcrisis reform agenda and ensuring that there is no push-back to the agenda that has already been agreed.

To conclude, it seems worthwhile to point out that today's risk management challenges are of a very different nature than the ones of past decades. While financial economists and the Wall Street quants were leading the intellectual underpinning of bond trading and risk management in the 1970s and 1980s, today researchers, risk managers, and regulators are catching up with a quickly changing environment that is shaped by unprecedented technological progress. New threats from cyber risks, high-frequency trading, and FinTech present analytical and practical challenges that are far from being tackled. These risks result in the massive technological advances of recent years that are constantly redefining opportunities and vulnerabilities in the financial system. We are far from being able to quantify these risks in a meaningful manner. There is, however, ample room for researchers to make substantial contributions to the nexus of risk management and regulations in today's world of radically reshaped financial technologies. 


\section{Bibliography}

Adrian, Tobias, and Nina Boyarchenko. 2016. "Intermediary Leverage Cycles and Financial Stability." Federal Reserve Bank of New York Staff Reports 567.

Adrian, Tobias, and Markus Brunnermeier. 2016. "CoVaR.” American Economic Review 106 (7): 1705-41.

Adrian, Tobias, and Hyun Song Shin. 2009. “The Shadow Banking System: Impli-cations for Financial Regulation.” Federal Reserve Bank of New York Staff Reports 382.

. 2010. "Liquidity and Leverage." Journal of Financial Intermediation 19 (3): 418-37.

. 2014. "Procyclical Leverage and Value-at-Risk." Review of Financial Studies 27 (2): 373-403.

Altman, Edward. 1968. "Financial Ratios, Discriminant Analysis and the Prediction of Corporate Bankruptcy." Journal of Finance 20: 589-609.

Ashcraft, Adam, and Til Schuermann. 2008. "Understanding the Securitization of Subprime Mortgage Credit." Federal Reserve Bank of New York Staff Reports 318.

Balla, Eliana, and Morgan Rose. 2012. "Loan Loss Reserves, Accounting Constraints, and Bank Ownership Structure.” Working Paper, Richmond, Federal Reserve Bank of Richmond.

Bangia, Anil, Francis Diebold, Andre Kronimus, Christian Schafer, and Til Schuermann. 2002. "Ratings Migration and the Business Cycle, with Applications to Credit Portfolio Stress Testing." Journal of Banking \& Finance 26 (2): 445-74.

Basel Committee on Banking Supervision (BCBS). 1999. "Capital Requirements and Bank Behavior: The Impact of the Basel Accord." Basel. 
_. 2009. "Enhancements to the Basel II Framework.” Basel. July.

_. 2011. "Basel III: A Global Regulatory Framework for More Resilient Banks and Banking Systems.” Basel.

- 2012. "Prudential Supervision of Netting, Market Risks and Interest Rate Risk - Preface to Consultative Proposal.” Basel.

Bernanke, Ben. 2005. "The Global Savings Glut and the U.S. Current Account Deficit." Sandridge Lecture at the Virginia Association of Econo $\neg$ mists, March 10.

Bernstein, Peter. 2012. Capital Ideas: The Improbable Origins of Modern Wall Street. Wiley.

Bharath, S., and T. Shumway. 2008. "Forecasting Default with the Merton Distance to Default Model." Review of Financial Studies 21: 1339-69.

Black, Fischer, Emanuel Derman, and William Toy. 1990. "A One-Factor Model of Interest Rates and Its Application to Treasury Bond Options." Financial Analysts Journal 46 (1): 33-39.

Black, Fischer, and Myron Scholes. 1973. "The Pricing of Options and Corporate Liabilities." Journal of Political Economy 81 (3): 637-54.

Bollerslev, Tim. 1986. "Generalized Autoregressive Conditional Heteroskedasticity." Journal of Econometrics 31: 307-27.

Brace, Alan, Dariusz Gatarek, and Marek Musiela. 1997. “The Market Model of Interest Dynamics.” Mathematical Finance 7 (2): 127-55.

Carney, John. 2012. "The SEC Rule That Broke Wall Street.” CBNC, March 21. https://www.cnbc.com/id/46808453.

Cohen, Benjamin, and Michela Scatigna. 2014. "Banks and Capital Requirements: Channels of Adjustment.” Working Paper 443, Bank for International Settlements.

Cox, John, Jonathan Ingersoll Jr., and Stephen Ross. 1985. "A Theory of the Term Structure of Interest Rates." Econometrica: 385-407.

Dagher, Jihad, Giovanni Dell'Ariccia, Luc Laeven, Lev Ratnovski, and Hui Tong. 2016. "Benefits and Costs of Bank Capital." IMF Staff Discussion Note 16/04, International Monetary Fund, Washington, DC.

Danielsson, Jón, Paul Embrechts, Charles Goodhart, Con Keating, Felix Muennich, Olivier Renault, Hyun Song Shin. 2001. "An Academic Response to Basel II.” Special Paper LSE Financial Markets Group.

Duffie, Darrell, Leandro Saita, and Ke Wang. 2007. "Multi-Period Corporate Default Prediction with Stochastic Covariates." Journal of Financial Economics 83 (3): 635-65. 
Duffie, Darrell, and Kenneth Singleton. 1999. "Modeling Term Structures of Default-able Bonds." Review of Financial Studies 12: 687-720.

—. 2003. Credit Risk: Pricing, Measurement, and Management. Princeton University Press.

Engle, Robert. 1982. "Autoregressive Conditional Heteroscedasticity with Estimates of the Variance of United Kingdom Inflation." Econometrica 50 (4): 987-1007.

Financial Stability Board (FSB). 2009a. "Principles for Sound Compensation Practices." Basel. April.

_. 2009b. "Implementation Standards for the FSB Principles for Sound Compensation Practices.” Basel.

—. 2010. "Principles for Reducing Reliance on CRAs." Basel.

_. 2011. "Key Attributes of Effective Resolution Regimes for Financial Institutions.” Basel.

_. 2012. "Roadmap for Reducing Reliance on CRA Ratings.” Basel.

—. 2015. "Transforming Shadow Banking into Resilient Market-based Finance.” Basel. November.

Fisher, Lawrence, and Roman Weil. 1971. "Coping with the Risk of Interest-Rate Fluctuations: Returns to Bondholders from Naïve and Optimal Strategies." Journal of Business 44 (4): 408-31.

Fong, H. Gifford, and Oldřich Vašíček. 1984. "A Risk Minimizing Strategy for Portfolio Immunization.” Journal of Finance 39: 1541-46.

Garbade, Kenneth. 1986. "Assessing Risk and Capital Adequacy for Treasury Secu-rities." Bankers Trust Company Money Market Center.

Geithner, Timothy. 2006. "Risk Management Challenges in the U.S. Financial System." Speech delivered to the Global Association of Risk Professionals, 7th Annual Risk Management Convention and Exhibition, New York, February 28.

Goetzmann, William, and K. Geert Rouwenhorst. 2008. "The History of Financial Innovation.” In Carbon Finance: Environmental Market Solutions to Climate Change, edited by B. Garcia and E. Roberts. Yale School of Forestry \& Environmental Studies.

Goodhart, Charles. 2011. The Basel Committee on Banking Supervision: A History of the Early Years 1974-1997. Cambridge University Press.

Gordy, Michael. 2003. "A Risk-Factor Model Foundation for Ratings-Based Bank Capital Rules.” Journal of Financial Intermediation 12: 199-232. 
, and B. Howells. 2006. "Procyclicality in Basel II: Can We Treat the Disease without Killing the Patient?" Journal of Financial Intermediation 15 (3): 395-417.

Gorton, Gary, and Andrew Metrick. 2012. "Securitized Banking and the Run on Repo." Journal of Financial Economics 104: 425-51.

Gupton, Greg, Christopher Finger, and Mickey Bhatia. 1997. CreditMetrics Technical Document. New York: JP Morgan.

Hardy, Charles. 1923. Risk and Risk-Bearing. Chicago: University of Chicago Press.

Heath, David, Robert Jarrow, and Andrew Morton. 1992. "Bond Pricing and the Term Structure of Interest Rates: A New Methodology for Contingent Claims Valuation.” Econometrica: 77-105.

Hicks, John. 1935. "A Suggestion for Simplifying the Theory of Money." Economica 2 (5): 1-19.

Homer, Sidney, and Martin Leibowitz. 1972. Inside the Yield Book. Englewood Cliffs, NJ: Prentice-Hall Inc.

Hull, John, and Alan White. 1994a. "Numerical Procedures for Implementing Term Structure Models I: Single-Factor Models." Journal of Derivatives 2 (1): 7-16.

1994b. "Numerical Procedures for Implementing Term Structure Models II: Two-Factor Models." Journal of Derivatives 2 (2): 37-48.

International Monetary Fund (IMF). 2006. Global Financial Stability Report. Washington, DC, April.

_. 2009. "Restarting Securitization Markets: Proposals and Pitfalls" In Global Financial Stability Report, Chapter 2, Washington, DC, October.

2011. "Towards Operationalizing Macroprudential Policies: When to Act?” In Global Financial Stability Report, Chapter 3, Washington, DC, October.

_ 2013. "Key Aspects of Macroprudential Policy." IMF Policy Paper, Washington, DC, June.

_. 2014. "IMF Staff Guidance Note on Macroprudential Policy." Washington, DC, November.

_ Financial Stability Board (FSB), and Bank for International Settlements (BIS). 2016. "Elements of Effective Macroprudential Polices: Lessons from International Experience.” August. 
International Organization of Securities Commissions (IOSCO). 2012.

"Global Developments in Securitisation Regulation: Final Report." Madrid, November.

Jorion, Philippe. 2006. Value at Risk: The Benchmark for Managing Financial Risk. 3rd ed. New York: McGraw Hill.

Kapan, Tumer, and Camelia Minoiu. 2017. "Balance Sheet Strength and Bank Lending: Evidence from the Global Financial Crisis.” Unpublished, April 5.

Kashyap, Anil, and Jeremy Stein. 2004. "Cyclical Implications of the Basel II Capital Standards." Federal Reserve Bank of Chicago Economic Perspectives 28 (1): 18-33.

Li, David. 2000. "Default Correlation: A Copula Approach.” Journal of Fixed Income: 43-54. March.

Macaulay, Frederick. 1938. Some Theoretical Problems Suggested by the Movements of Interest Rates, Bond Yields and Stock Prices in the United States since 1856. NBER Books.

McDonald, Robert, and Anna Paulson. 2015. "AIG in Hindsight." Journal of Economic Perspectives 29 (2): 81-106.

McGuinness, John. 1969. "Is Probable Maximum Loss (PML) a Useful Concept?" Proceedings of the Casualty Actuarial Society 56 (105).

McLean, Bethany. 2012. "The Meltdown Explanation that Melts Away." Reuters. March 19 (http://blogs.reuters.com/bethany-mclean/2012/03/19/ the-meltdown-explanation-that-melts-away/).

Merton, Robert. 1973. "Theory of Rational Option Pricing." Bell Journal of Economics and Management Science: 141-83. 1974. "On the Pricing of Corporate Debt: The Risk Structure of Interest Rates." Journal of Finance 29: 449-70.

Mills, Paul, and John Kiff. 2007. "Money for Nothing and Checks for Free : Recent Developments in U.S. Subprime Mortgage Markets." IMF Working Paper 07/188. Washington, IMF.

Morgan Guaranty. 1994. RiskMetrics. Technical Document, 1st ed. New York.

Ong, Li, ed. 2014. A Guide to IMF Stress Testing: Methods and Models. Washington, DC: International Monetary Fund.

Paech, Philipp. 2016. "The Value of Financial Market Insolvency Safe Harbours." Oxford Journal of Legal Studies 36 (4): 855-84. 
Pesaran, M. Hashem, Til Schuermann, Björn-Jakob Treutler, and Scott Weiner . 2006. "Macroeconomic Dynamics and Credit Risk: A Global Perspective." Journal of Money, Credit and Banking 38 (5): 1211-61.

Plosser, Matthew, and João Santos. 2014. “Banks' Incentives and the Quality of Internal Risk Models." Federal Reserve Bank of New York Staff Reports 704.

Repullo, Rafael, and Javier Suarez. 2008. "The Procyclical Effects of Basel II.” CEPR Discussion Paper 6862.

Roy, Arthur. 1952. "Safety First and the Holding of Assets." Econometrica: 431-49.

Shumway, Tyler. 2001. "Forecasting Bankruptcy More Accurately: A Simple Hazard Model." Journal of Business 74: 101-24.

Snowden, Kenneth. 2007. "Mortgage Companies and Mortgage Securitization in the Late Nineteenth Century." Unpublished, University of North Carolina.

Vašíček, Oldřich. 1977. "An Equilibrium Characterization of the Term Structure." Journal of Financial Economics 5: 177-88.

_. 1987. "Probability of Loss on Loan Portfolio." Unpublished, KMV Corporation.

—. 2002. "Loan Portfolio Value." Risk 15: 160-62.

White, Eugene. 2009. "Lessons from the Great American Real Estate Boom and Bust of the 1920s.” NBER Working Paper 15573. 